\title{
MODEL PAIKEM DALAM MENINGKATKAN MINAT BELAJAR SISWA PADA MATA PELAJARAN AL-QUR'AN HADITS DI MADRASAH TSANAWIYAH LABORATORIUM KOTA JAMBI
}

\author{
Yulianto \\ Institut Agama Islam Yasni Bungo \\ e-mail: antoyuli07624@gmail.com \\ Ana Rosyidatu Umatin \\ Institut Agama Islam Yasni Bungo \\ e-mail: anarosyida@gmail.com \\ Ulfa Adilla \\ Institut Agama Islam Yasni Bungo \\ e-mail: adillahasan@gmail.com \\ Laili Rahmi \\ Institut Agama Islam Yasni Bungo \\ e-mail: lailirahmi09@gmail.com
}

\begin{abstract}
This study aimed to examining PAIKEM teaching strategy in improving students' interest in subject Al-Quran Hadist at MTs Laboratory of Jambi city which was still low. This reseach applied qualitative approach that was descriptive analytical. Data collection was conducted using observation, interview and documentation. Determination of reseach subjects used purposive sampling tecnique. Data analysis tecniques were perfomed by data reduction, data presentation and conclusion and verification of reliability of reseach result obtained by extension techniques of participation, occuracy of observation, data triangulation and consultation. The result of this study indicated that effectiveness of PAIKEM teaching strategy to increase sudents' interest in subjects Al-Quran Hadits at MTs Laboratory Jambi city has not been achieved because teachers prepared the learning ,aterials with limited facilities. Teachers also carried out active, innovative, creative, effective and fun learning and the also chose and used limited learning tools and media, however they still provided stimuli to students such as encouraging students to study hard, rewar and punishment, paying attention to each students individual development in classroom learning. Teachers also conducted evaluations to ensure that learning activity conducive. The conclusion of this research was that PAIKEM teaching strategy in improving students interest in subjects Al-Quran Hadits at MTs Laboratory of Jambi city because this strategy had not yet given enaough attention to students' psychology and their needs in learning.
\end{abstract}

Keyword: Strategy, PAIKEM, Learning interest.

Nur El-Islam, Volume 8, Nomor 1, April 2021 


\begin{abstract}
Abstrak
Penelitian ini bertujuan untuk mengkaji model PAIKEM dalam meningkatkan minat belajar siswa pada mata pelajaran Al-Qur'an Hadits di MTs Laboratorium Kota Jambi yang masih rendah. Penelitian ini menggunakan pendekatan kualitatif bersifat deskriptif analitis. Pengumpulan data dilakukan dengan teknik observasi, wawancara dan dokumentasi. Penentuan subjek penelitian menggunakan teknik purposive sampling. Teknik analisis data dilakukan dengan reduksi data, penyajian data dan penarikan kesimpulan serta verifikasi keterpercayaan hasil penelitian diperoleh dengan teknik perpanjangan keikutsertaan, ketelitian pengamatan, triangulasi data dan konsultasi pembimbing. Hasil penelitian ini menunjukkan bahwa efektivitas PAIKEM untuk meningkatkan minat belajar siswa pada mata pelajaran Al-Qur'an Hadits di MTs Laboratorium Kota Jambi belum tercapai. Meskipun guru melaksanakan pembelajaran aktif, inovatif, kreatif, efektif dan menyenangkan memilih dan menggunakan alat dan media pembelajaran yang terbatas, namun tetap memberikan stimuli kepada siswa seperti mendorong siswa giat belajar, memberikan reward dan punishment, memperhatikan perkembangan invidual setiap siswa dalam belajar di kelas. Guru juga melakukan evaluasi untuk memastikan belajar tetap kondusif. Kesimpulan penelitian ini adalah model PAIKEM dalam meningkatkan minat belajar siswa pada mata pelajaran Al-Qur'an Haditsdi MTs Laboratorium Kota Jambi karena belum optimal memperhatikan psikologi dan kebutuhan belajar siswa.
\end{abstract}

Kata Kunci: Model PAIKEM, Minat Belajar

\title{
A. PENDAHULUAN \\ 1. Latar Belakang Masalah
}

Di era kontemporer ini, PAIKEM sangat dianjurkan mengingat semakin kompleknya permasalahan di dunia pendidikan dan juga besarnya tuntutan yang dibebankan kepada guru dalam mensukseskan pembelajaran di tingkat sekolah ataupun para dosen di tingkat perguruan tinggi. Model PAIKEM adalah sebuah model dan terobosan pembelajaran yang memungkinkan peserta didik untuk mengerjakan kegiatan yang beragam dalam rangka mengembangkan ketrampilan dan pemahamannya, dengan penekanan peserta didik belajar sambil bekerja, sementara guru menggunakan berbagai sumber dan alat bantu belajar (termasuk pemanfaatan lingkungan), supaya pembelajaran lebih menarik, menyenangkan dan efektif. ${ }^{1}$ Di dalam

1 Masitoh dan Laksmi Dewi, Strategi Pembelajaran (Jakarta: Direktorat Jenderal Pendidikan Islam Departemen Agama RI, 2009), hal. 259. 
sistem pendidikan dari prinsip-prinsip pembelajaran tradisional yang berpusat pada guru (teacher centered) menjadi pembelajaran yang berpusat pada siswa (student centered). UU No. 20 Tahun 2003 Bab XI Pasal 40 ayat 2a menyatakan bahwa pendidik dan tenaga kependidikan berkewajiban menciptakan suasana pendidikan yang bermakna, menyenangkan, kreatif, dinamis dan dialogis, dipertegas dengan Permendiknas No.41 tahun 2007 tentang pelaksanaan PAIKEM. ${ }^{2}$

PAIKEM juga membuka ruang pada guru dan siswa melakukan kreativitas bersama-sama. Guru akan berusaha untuk melibatkan semua siswa dalam proses pembelajaran dengan kreasi-kreasi baru. Sementara itu, siswa juga didorong agar kreatif dalam berinteraksi dengan sesama teman, guru, materi pelajaran, dan segala alat bantu belajar. ${ }^{3}$

Pembelajaran Al-Qur'an Hadits di MTs Laboratorium Kota Jambi merupakan salah satu dari rumpun bidang studi Pendidikan Agama Islam (PAI) yang memberikan pendidikan kepada peserta didik untuk memahami dan mencintai Aqidah dan Akhlak dari sumber ajaran Islam yaitu Al-Qur'an dan Sunnah sertamengamalkan isi kandungannya dalam kehidupannya sehari-hari. Al-Qur'an merupakan pedoman bagi seluruh umat manusia di dunia. Maka untuk bisa mengamalkan isi dari Al-Qur'an dengan menunjukkan akhlak yang baik. Sedangkan tujuan pembelajaran Al-Qur'an Hadits menurut Abdurrahman Saleh sebagaimana dikutip Syahidin, berpendapat bahwa karekteristik tujuan umum pendidikan Islam adalah diarahkan pada hal-hal yang berhubungan dengan persiapan-persiapan untuk memperoleh kebahagiaan hidup di dunia dan akhirat. ${ }^{4}$

Berdasarkan grand tour di MTs Laboratorium Kota Jambi menemukan masalah:Pertama, minat belajar 10 orang siswa masih

2 Marsih, Analisis Pengembangan PAIKEM dalam Peningkatan Mutu Pendidikan Dasar di Kecamatan Singosari Kabupaten Malang, Tesis, (Program Pascasarjana Universitas Muhammadiyah Malang, 2011), hal. 8.

3 Rudi Hartono, Ragam Model Mengajar yang Mudah Diterima Murid (Yogyakarta: Diva Press, 2013), hal. 135-137.

4 Syahidin, Menelusuri Metode Pendidikan dalam Al-Qur'an (Bandung: Alfabeta, 2009), hal. 10. 
rendah dari 21 orang siswa di kelas VIII E. Hal ini dapat dilihat dari segi pertama keterlibatan siswa seperti siswa tidak aktif dalam berdiskusi, jarang bertanya, timbul perasaan bosan, tidak semangat mengikuti pelajaran, kurang serius mendengarkan penjelasan gurunya, dan kadang siswa tidak mencatat materi yang disampaikan oleh guru. ${ }^{5}$ Kedua, guru Al-Qur'an Hadits masih belum optimal dalam menerapkan model yang menyenangkan sehingga siswa tidak timbul keceriaan dan minat untuk mengikuti pembelajaran. Penyajian materi cenderung datar dengan suara yang jelas, namun kurang ekspesif. ${ }^{6}$ Ketiga, guru Al-Qur'an Hadits masih belum optimal dalam meningkatkan minat belajar siswa, indikasinya siswa bosan belajar, tidak fokus menerima pelajaran, semangat dan ketekunan belajar siswa yang masih rendah dan ada kebosanan pada diri siswa untuk belajar. $^{7}$

Dengan efektifnya penerapan model PAIKEM ini diharapkan minat belajar siswa lebih meningkat, karena guru telah memberikan suatu pembelajaran yang menyenangkan serta tidak membosankan. Berbagai cara yang diterapkan oleh seorang guru. “Arti dari minat belajar yaitu, minat adalah suatu keadaan dimana seseorang mempunyai perhatian terhadap sesuatu dan disertai dengan keinginan untuk mengetahui dan mempelajarinya maupun membuktikannya. ${ }^{8}$

\section{Rumusan Masalah}

Berdasarkan uraian di atas, permasalahan dalam penelitian ini adalah pertanyaan pokok dalam penelitian ini adalah

1. Bagaimana efektivitas PAIKEM untuk meningkatkan minat belajar siswa pada mata pelajaran Al-Qur'an Hadits di MTs Laboratorium Kota Jambi?

2. Bagaimana upaya guru Al-Qur'an Haditsuntuk meningkatkan minat belajar siswa di MTs Laboratorium Kota Jambi?

5 Observasi, di MTs Laboratorium Kota Jambi

6 Observasi, di MTs Laboratorium Kota Jambi

7 Wawancara, di MTs Laboratorium Kota Jambi hal. 91 .

${ }^{8}$ Ramayulis, Metodologi Pengajaran Agama Islam (Jakarta: Kalam Mulia, 2001), 
3. Bagaimana faktor pendukung dan penghambat pembelajaran PAIKEM dalam meningkatkan minat belajar siswa pada mata pelajaran Al-Qur'an Hadits di MTs Laboratorium Kota Jambi?

3. Teori/Kajian

\section{a. Model PAIKEM}

Model PAIKEM adalah sebuah model dan terobosan pembelajaran yang memungkinkan peserta didik untuk mengerjakan kegiatan yang beragam dalam rangka mengembangkan keterampilan dan pemahamannya, dengan penekanan peserta didik belajar sambil bekerja, sementara guru menggunakan berbagai sumber dan alat bantu belajar (termasuk pemanfaatan lingkungan), supaya pembelajaran lebih menarik, menyenangkan dan efektif. ${ }^{9}$

PAIKEM juga membuka ruang pada guru dan siswa melakukan kreativitas bersama-sama. Guru akan berusaha untuk melibatkan semua siswa dalam proses pembelajaran dengan kreasi-kreasi baru. Sementara itu, siswa juga didorong agar kreatif dalam berinteraksi dengan sesama teman, guru, materi pelajaran, dan segala alat bantu belajar. ${ }^{10}$

Dapat disimpulkan bahawa Model PAIKEM adalah sebuah pembelajaran yang memungkinkan peserta didik untuk mengerjakan kegiatan yang beragam dalam rangka mengembangkan keterampilan dan pemahamannya, dengan penekanan peserta didik belajar sambil bekerja, sementara guru menggunakan berbagai sumber dan alat bantu belajar (termasuk pemanfaatan lingkungan), supaya pembelajaran lebih menarik, menyenangkan dan efektif. Indikator model PAIKEM adalah pembelajaran yang mengedepannya keterampilan dan pemahamannya dengan bekerja menggunakan media.

\section{b. Minat Belajar}

Minat (interes) berarti kecenderungan dan kegairahan yang tinggi atau keinginan yang besar terhadap sesuatu atau asa ingin tahu,

\footnotetext{
9 Masitoh dan Laksmi Dewi, Op. Cit., hal. 259

${ }^{10}$ Rudi Hartono, Op. Cit., hal. 135-137.
} 
seperti belajar dan membaca. ${ }^{11}$ Minat merupakan gejala psikologis yang bisa berpengaruh untuk melakukan sesuatu. Minat menjadi salah satu penentu seseorang ingin mengerjakan sesuatu dan minat menjadikan seseorang memiliki cita-cita yang tinggi.

Interest is persisting tendency to pay attention to and enjoy same activities and content. (Minat adalah kecenderungan yang tetapuntuk memperhatikan dan mengenang beberapa kegiatan). ${ }^{12}$ Pada dasarnya, minat mengarahkan perbuatan pada suatu tujuan dan merupakan dorongan bagi perbuatan itu. Dalam diri manusia terdapat dorongandorongan (motif-motif) yang mendorong manusia untuk berinteraksi dengan dunia luar. Motif menggunakan dan menyelidiki dunia luar (Manipulate and exploring motives). Dari explorasi yang dilakukan terhadap dunia luar itu, lama kelamaan timbullah minat terhadap sesuatu. Apa yang menarik minat seseorang mendorongnya untuk berbuat lebih giat dan lebih baik. ${ }^{13}$

Dapat disimpulkan bahwa Minat belajar adalah perhatian, rasa suka, ketertarikan seseorang (peserta didik) terhadap belajar yang ditunjukkan melalui keantusiasan, partisipasi dan keaktifan dalam belajar. Indikator minat adalah perasaan senang, perhatian dalam belajar, siswa senang dengan bahan pelajaran dan sikap guru yang menarik.

\section{Metodologi Penelitian}

\section{a. Metodologi Penelitian}

Penelitian ini menggunakan pendekatan kualitatif bersifat deskriptif analitis. Pengumpulan data dilakukan dengan teknik observasi, wawancara dan dokumentasi. Penentuan subjek penelitian menggunakan teknik purposive sampling. Teknik analisis data dilakukan dengan reduksi data, penyajian data dan penarikan kesimpulan serta verifikasi keterpercayaan hasil penelitian diperoleh

${ }^{11}$ Muhibbin Syah, Psikologi Belajar (Jakarta: RajaGrafindo Persada, 2008), hal. 151.

${ }^{12}$ Daryanto, Belajar dan Mengajar (Bandung: CV. Yrama Widya, 2010), hal. 38.

${ }^{13}$ Abdul Rahman Shaleh, Psikologi Suatu Pengantar dalam Perspektif Islam (Jakarta: Kencana Prenada Media Group, 2009), hal. 261-262. 
Yulianto, Ana Rasyidatu Umatin, Ulfa Adilla, Laili Rahmi

dengan teknik perpanjangan keikutsertaan, ketelitian pengamatan, triangulasi data.

\section{B. PEMBAHASAN}

a. Efektivitas PAIKEM untuk meningkatkan minat belajar siswa pada mata pelajaran Al-Qur'an Hadits di MTs Laboratorium Kota Jambi.

Efektivitas PAIKEMuntuk meningkatkan minat belajar siswa pada mata pelajaran Al-Qur'an Hadits di MTs Laboratorium Kota Jambi bisa diketahui dari tiga proses berikut ini:

\section{Minat Siswa Sebelum Menggunakan Model PAIKEM}

Sebelum membahas efektivitas PAIKEM untuk meningkatkan minat belajar siswa, maka disajikan minat siswa selama belajar pada mata pelajaran Al-Qur'an Hadits di MTs Laboratorium Kota Jambi. Motivasi merupakan elemen penting yang membantu siswa menyenangi mata pelajaran yang dipelajarinya. Tentu guru tidak ingin bila tujuan pendidikan dan pembelajaran yang telah direncanakan tidak tercapai melihat siswa tidak memiliki minat sedikitpun. Pengamatan penulis di kelas VIII saat siswa mengikuti proses pembelajaran mata pelajaran Al-Qur'an Hadits dimana ada beberapa siswa yang kurangnya keinginan untuk belajar. Mereka tidak konsentrasi dalam belajar dan terlihat kesulitan dalam mengikuti kegiatan pembelajaran pada mata pelajaran tersebut. ${ }^{14}$ Pelaksanaan pembelajaran PAIKEM berusaha memperhatikan motivasi sebagai salah satu faktor penentu keberhasilan pembelajaran. Jika tidak, maka kondisi ini tentu membuat siswa kesulitan dalam menerima materi terjadi karena minat siswa sangat kurang sekali.

Hasil observasi penulis di kelas VIII menemukan bahwa siswa terbilang kurang begitu aktif dan antusias dalam mengikuti pelajaran. Keaktifan belum terjadi pada sebagian siswa, mereka tidak bertanya atau merespon materi yang diberikan guru, dalam satu kali pertemuan rata- rata hanya ada sekitar satu atau dua kali pertanyaan yang dilontarkan siswa kepada guru untuk bertanya masalah materi yang

${ }^{14}$ Observasi, di MTs Laboratorium Kota Jambi 
kurang jelas ${ }^{15}$ Paksanaan pembelajaran perlu dilakukan dengan tenang dan menyenangkan, hal tersebut tentu saja menuntut aktivitas dan kreativitas guru dalam menciptakan suasana pembelajaran yang kondusif, kegiatan inti pembelajaran atau pembentukan kompetensi dikatakan efektif apabila seluruh peserta didik terlibat aktif; baik secara mental maupun sosialnya.

Siswa akan semangat belajar apabila hasil belajarnya dipuji atau diperhatikan. Dari pengamatan penulis ada sebagian siswa yang merasa iri dengan siswa yang mendapat pujian dan perhatian ekstra dari guru Al-Qur'an Haditsnya ketika berada di dalam kelas. Mereka malas belajar karena menganggap guru pilih kasih dalam memberikan kasih sayang kepada siswa. ${ }^{16}$

Hasil observasi penulis di kelas VIII menemukan bahwa siswa terbilang kurang begitu aktif dan antusias dalam mengikuti pelajaran. Keaktifan belum terjadi pada sebagian siswa, mereka tidak bertanya atau merespon materi yang diberikan guru, dalam satu kali pertemuan rata- rata hanya ada sekitar satu atau dua kali pertanyaan yang dilontarkan siswa kepada guru untuk bertanya masalah materi yang kurang jelas ${ }^{17}$ Paksanaan pembelajaran perlu dilakukan dengan tenang dan menyenangkan, hal tersebut tentu saja menuntut aktivitas dan kreativitas guru dalam menciptakan suasana pembelajaran yang kondusif, kegiatan inti pembelajaran atau pembentukan kompetensi dikatakan efektif apabila seluruh peserta didik terlibat aktif; baik secara mental maupun sosialnya.

Motivasi intrinsik ini merupakan kegiatan belajar dimulai dan diteruskan, dan berdasarkan penghayatan suatu kebutuhan dan dorongan yang secara mutlak berkaitan dengan aktivitas belajar yang berasal dari dalam diri siswa sendiri. Faktor ini menyangkut diri pribadi dari siswa itu sendiri, mereka kurang begitu berusaha untuk serius dalam belajar atau boleh dikatakan tidak adanya usaha untuk meningkatkan usaha mereka agar merubah sistem belajar mereka

${ }^{15}$ Observasi, di MTs Laboratorium Kota Jambi

${ }^{16}$ Observasi, di MTs Laboratorium Kota Jambi

${ }^{17}$ Observasi, di MTs Laboratorium Kota Jambi 
menuju cara yang lebih baik. Seperti halnya mata pelajaran lain, pada mata pelajaran Al-Qur'an Hadits juga sangat membutuhkan sebuah motivasi yang kuat untuk mempelajarinya. Terlepas dari motivasi yang diberikan guru kepada siswanya, siswa juga berusaha memotivasi diri untuk sebisa mungkin menyenangi mata pelajaran tersebut.

Dalam melaksanakan proses pembelajaran PAIKEM di kelas tidak terlepas dengan motivasi siswa itu sendiri, karena dengan adanya motivasi yang tinggi terhadap suatu pelajaran atau kegiatan, maka siswa itu akan sungguh-sungguh belajar. Kesungguhan ini tentu nantinya bisa mempengaruhi keberhasilannya dalam belajar. Wawancara penulis dengan SM, guru Al-Qur'an Hadits yang mengatakan bahwa rendahnya motivasi siswa dalam belajar dan mengikuti suatu kegiatan pembelajaran menyebabkan mereka kesulitan untuk belajar. Kesulitan ini terbentuk karena kurangnya keinginan mereka untuk belajar, tidak perhatian dalam belajar, ribut di kelas serta kurangnya keinginan mereka untuk mempelajari ilmu pengetahuan pada berbagai bidang studi yang seharusnya mereka pelajari. $^{18}$

Lebih lanjut observasi pada kelas dan materi pelajaran yang sama maka ditemukan ada tiga metode belajar yang digunakan guru dalam pembelajaran Al-Qur'an Hadits yang berlangsung di kelas tersebut. Pada saat guru memberikan materi secara ceramah, terlihat ada 2 siswa yang tidak begitu aktif mengikuti pelajaran atau terlihat tidak bersemangat mengikuti pembelajaran yang berlangsung. Namun guru segera menyadari hal itu dengan memberikan sejumlah pertanyaan tentang permasalahan yang dihadapi. Selanjutnya siswa yang diberikan perhatian oleh guru terlihat bisa mengikuti pelajaran dengan baik, bahkan ikut bertanya pada saat tanya jawab berlangsung. ${ }^{19}$

Faktor ini menyangkut diri pribadi dari siswa itu sendiri, mereka kurang begitu berusaha untuk serius dalam belajar atau boleh dikatakan tidak adanya usaha untuk meningkatkan usaha mereka agar

\footnotetext{
${ }^{18}$ Wawancara, di MTs Laboratorium Kota Jambi

${ }^{19}$ Observasi, di MTs Laboratorium Kota Jambi
} 
merubah sistem belajar mereka menuju cara yang lebih baik. Seperti halnya mata pelajaran lain, pada mata pelajaran Al-Qur'an Hadits juga sangat membutuhkan keinginan yang kuat untuk mempelajarinya. Kesungguhan ini tentu nantinya bisa mempengaruhi hasil belajar. Wawancara penulis dengan SM, guru Al-Qur'an Hadits yang mengatakan bahwa rendahnya hasil siswa dalam belajar dan mengikuti suatu kegiatan pembelajaran menyebabkan mereka kesulitan untuk belajar. Kesulitan ini terbentuk karena kurangnya keinginan mereka untuk belajar, tidak perhatian dalam belajar, ribut di kelas serta kurangnya keinginan mereka untuk mempelajari ilmu pengetahuan pada berbagai bidang studi yang seharusnya mereka pelajari. $^{20}$

Tentu guru tidak ingin bila tujuan pendidikan dan pembelajaran PAIKEM yang telah direncanakan tidak tercapai melihat siswa tidak memiliki keinginan belajar sedikitpun. Pengamatan penulis di kelas VIII saat siswa mengikuti proses pembelajaran mata pelajaran AlQur'an Hadits dimana ada beberapa siswa yang kurangnya keinginan untuk belajar. Mereka tidak konsentrasi dalam belajar dan terlihat kesulitan dalam mengikuti kegiatan pembelajaran pada mata pelajaran tersebut. ${ }^{21}$ Pelaksanaan pembelajaran harus memperhatikan psikologi siswa sebagai salah satu faktor penentu hasil belajar. Jika tidak, maka kondisi ini tentu membuat siswa kesulitan dalam menerima materi.

Hasil observasi di kelas VIII di MTs Laboratorium Kota Jambi pada materi Thaharah ditemukan bahwa guru menemukan siswa yang kesulitan dalam memahami materi pelajaran Al-Qur'an Hadits. Apalagi jika ada materi pelajaran yang khusus membaca, menghapal atau menulis dengan huruf arab pada mata pelajaran Al-Qur'an Hadits tersebut, sehingga guru melakukan diskusi belajar dan terlihat siswa menceritakan kesulitan belajar mereka yang salah satunya karena ketidaklancaran membaca huruf-huruf Arab. ${ }^{22}$

\footnotetext{
${ }^{20}$ Wawancara, di MTs Laboratorium Kota Jambi

${ }^{21}$ Observasi, di MTs Laboratorium Kota Jambi

${ }^{22}$ Observasi, di MTs Laboratorium Kota Jambi
} 
Wawancara dengan siswa kelas VIII di MTs Laboratorium Kota Jambi sebagai berikutkarena saya kurang lancar membaca ayat-ayat AlQur'an maupun Hadist, dan lambat sekali menghapalnya. Maka guru membimbing saya untuk belajar memberikan saya kesempatan untuk menghapalnya di rumah, dan guru juga menekankan kepada saya tidak perlu ragu untuk bertanya kepada guru jika saya kesulitan lagi dalam membaca. ${ }^{23}$ Berdasarkan observasi di atas, dapat diketahuai bahwa guru telah memiliki model yang tepat dalam membangkitkan motivasi siswa dalam pembelajaran mata pelajaran Al-Qur'an Hadits melalui interaksi guru dan siswa.

\section{b. Upaya Guru Al-Qur'an Haditsuntuk Meningkatkan Minat Belajar Siswa di MTs Laboratorium Kota Jambi}

Pemahaman guru dalam bidang landasan kependidikan dan psikologi pendidikan sangat membantu siswa menyenangi mata pelajaran yang dipelajarinya sesuai tujuan PAIKEM. Seperti halnya pada mata pelajaran yang lain, pada mata pelajaran Al-Qur'an Hadits motivasi belajar juga sangat dibutuhkan. Tentu guru tidak ingin bila tujuan pendidikan dan pembelajaran yang telah direncanakan tidak tercapai melihat siswa tidak memiliki motivasi sedikitpun untuk mempelajari mata pelajaran Al-Qur'an Hadits. Pelaksanaan pembelajaran pada mata pelajaran Al-Qur'an Hadits harus memperhatikan motivasi ini sebagai salah satu faktor penentu keberhasilan pembelajaran. Berikut disajikan pelaksanaan pembelajaran mata pelajaran Al-Qur'an Hadits dengan melihat kondisi motivasi siswa di dalam pelaksanaan pembelajaran tersebut. Stimulus belajar dari guru dalam meningkatkan minat belajar siswa pada mata pelajaran Al-Qur'an Hadits di MTs Laboratorium Kota Jambi yaitu:

\section{a. Memberi Angka}

Hasil belajar dengan angka yang baik tentu bisa memotivasi siswa untuk mencapainya lagi pada waktu berikutnya, dan sebaliknya siswa menjadi termotivasi jika angka angka yang diraihkan belum

\footnotetext{
${ }^{23}$ Wawancara, di MTs Laboratorium Kota Jambi
} 
begitu baik. Observasi terhadap SM, guru yang mengajar Al-Qur'an Hadits sebagai berikut supaya siswa aktif dan penyajian materi menyenangkan mengajar di kelas, maka guru memanfaatkan pemberian angka ini untuk meningkatkan minat siswa dalam belajar pada mata pelajaran Al-Qur'an Hadits. Di kelas VIII ini saja menggunakan angka untuk menilai hasil kerja siswa. Angka penilaian yang saya gunakan seperti 10, 9, 8 dan seterusnya. Dengan pemberian angka ini siswa menjadi termotivasi untuk mencapai angka yang lebih baik dalam belajar. ${ }^{24}$

Berdasarkan wawancara dengan guru yang mengajar Al-Qur'an Hadits dimana ia memanfaatkan pemberian angka ini dalam meningkatkan minat belajar siswa. Upaya membangkitkan motivasi siswa yang dilakukan guru Al-Qur'an Hadits dapat mendorong peserta didik untuk aktif dalam kegiatan belajar. Wawancara dengan guru yang mengajar Al-Qur'an Hadits di kelas VIII yaitu SMyang mengatakan bahwa saya memang mengajak siswa mengulangi pelajaran yang telah lalu. Karena minat belajar siswa masih rendah, maka saya memberikan nilai bagi siswa yang bisa menjawab pertanyaan yang saya ajukan dijawab dengan benar oleh siswa. Terlihat siswa antusias menjawab pertanyaan yang saya berikan karena mereka termotivasi untuk mendapatkan nilai. ${ }^{25}$

Observasi terhadap siswa kelas VIII yang mengikuti proses pembelajaran Al-Qur'an Haditsdi mana siswa aktif dan senang belajar. Siswa yang bisa menjawab pertanyaan yang diajukan guru dan dijawab dengan benar. Siswa berkeinginan menjawab pertanyaan yang diberikan karena ingin mendapatkan nilai tambahan belajar seperti pertanyaan mengenai nama-nama Nabi dan Rasul Allah SWT.”26

Wawancara dengan siswa kelas VIII yang mengikuti proses pembelajaran Al-Qur'an Hadits mengatakan bahwa di awal pembelajaran di kelas guru mata pelajaran Al-Qur'an Hadits biasanya memberikan sejumlah pertanyaan kepada kami untuk dijawab

\footnotetext{
${ }^{24}$ Observasi, di MTs Laboratorium Kota Jambi

${ }^{25}$ Wawancara, di MTs Laboratorium Kota Jambi

${ }^{26}$ Observasi, di MTs Laboratorium Kota Jambi
} 
mengenai materi pelajaran yang telah lalu. Jika kami bisa menjawab maka akan mendapatkan nilai. Saya menjadi ingin menjawabnya dan terkadang jawaban saya benar dan mendapatkan nilai. ${ }^{27} \mathrm{Guru}$ dapat mengetahui tingkat kemajuan siswa jika guru melakukannya dalam proses pembelajaran PAIKEM dengan meningkatkan minat belajar siswa. Dengan demikian, maka siswa mengetahui materi yang pernah mereka pelajari.

b. Mengetahui Hasil Belajar

Guru mata pelajaran Al-Qur'an Hadits juga memberikan informasi yang sejelas-jelasnya mengenai kemajuan dan kemunduran siswa dalam belajar. Dengan demikian siswa menjadi termotivasi untuk berbenah diri dan meningkatkan minat belajar mereka dalam belajar. Observasi penulis terhadap SM, guru yang mengajar Al-Qur'an Hadits di kelas VIII sebagai berikut bahwa nampak atau terlihat berusaha memberikan informasi sebanyak mungkin kepada siswa tentang perkembangan belajar mereka setiap waktu pada mata pelajaran Al-Qur'an Hadits seperti memberikan informasi hasil ulangan harian, hasil ulangan mingguan, hasil ulangan bulanan dan hasil ulangan semester. Ini dimaksudkan agar siswa bisa termotivasi dengan mengetahui hasil belajar yang mereka peroleh, dan siswa bisa berkesempatan memperbaikinya pada masa yang akan datang. ${ }^{28}$ Berdasarkan wawancara dengan guru mata pelajaran Al-Qur'an Hadits di kelas VIII MTs Laboratorium Kota Jambi dimana dikatakan bahwa upaya lain yang telah dilakukan untuk meningkatkan minat belajar siswa adalah dengan cara memberikan kesempatan siswa mengetahui hasil belajar mereka dari setiap waktu.

\section{c. Memberi Pujian Kepada Siswa}

Pada awalnya kemauan siswa dalam mempelajari Al-Qur'an Hadits masih sangat kurang, hal ini terlihat lemah dari pemahaman siswa terhadap pelajaran yang sudah diberikan oleh guru. Wawancara dengan SM, guru yang mengajar Al-Qur'an Hadits di kelas VIII sebagai berikut pada pertemuan awal dalam proses pembelajaran Al-Qur'an

\footnotetext{
${ }^{27}$ Wawancara, di MTs Laboratorium Kota Jambi

${ }^{28}$ Observasi, di MTs Laboratorium Kota Jambi
} 
Hadits, masih sulit bagi saya untuk melihat kemauan siswa yang betulbetul ingin mempelajari dan memahami pelajaran dengan baik, karena siswa ada tidak begitu serius mengikuti proses pembelajaran. Untuk itu saya memuji siswa yang benar-benar pintar dan berpeluang untuk berprestasi. Hal ini saya lakukan pada saat-saat tertentu. ${ }^{29}$

Observasi penulis menemukan bahwa tindakan yang dilakukan guru Al-Qur'an Hadits dalam meningkatkan pelaksanaan pembelajaran salah satunya adalah memberikan pujian bagi anakanak yang terlihat sungguh-sungguh belajar dan memberikan dorongan semangat belajar untuk terus belajar lebih giat lagi dari sebelumnya. Bagi anak yang kurang sungguh-sungguh belajar maka anak tersebut diajak untuk berdialog mengenai kesulitan belajar AlQur'an Hadits dan dicari solusi pemecahan masalahnya. Guru memberi pujian tidak tiap kali mengajar, namun sesekali seperti saat membagikan hasil belajar seperti hasil ulangan ataupun hasil tugas di rumah yang dikerjakan siswa. ${ }^{30}$

Observasi terhadap siswa kelas VIII yang mengikuti pembelajaran studi Al-Qur'an Hadits dimana guru selalu memberikan pujian kepada siswa yang sungguh-sungguh mengikuti pembelajaran yang dilakukan jika menerima nilai ulangan atau nilai pekerjaan rumah. Kata-kata yang digunakan guru misalnya "nilai kamu bagus nak, tingkatkan lagi ya”. Di samping itu guru juga membantu memecahkan masalah siswa jika siswa kesulitan belajar di kelas. ${ }^{31}$

Guru menyadari hal ini sangat berguna bagi peningkatan minat belajar siswa dalam pembelajaran pada masa yang akan datang pada mata pelajaran Al-Qur'an Hadits. Faktor-faktor di dalam kegiatan pembelajaran sangat banyak sekali di antaranya adalah interaksi antara guru dan anak didiknya. Bila kedua faktor ini tidak baik keadaannya, maka minat belajar siswa dalam proses pembelajaran PAIKEMpada mata pelajaran Al-Qur'an Hadits yang dicapai tidak sempurna pula. Pengamatan di kelas VIII sebagai berikut yaitu

\footnotetext{
${ }^{29}$ Wawancara, di MTs Laboratorium Kota Jambi

${ }^{30}$ Observasi, di MTs Laboratorium Kota Jambi

${ }^{31}$ Observasi, di MTs Laboratorium Kota Jambi
} 
komunikasi guru dengan siswa terjalin sangat akrab. Tidak nampak guru memarahi atau menghukum siswa. Di samping itu tidak nampak siswa mengeluarkan kata-kata yang tidak sopan di depan guru yang mengajar di kelas saat pembelajaran mata pelajaran Al-Qur'an Hadits. Terlihat guru selalu memberikan pujian kepada siswa yang berprestasi dan melakukan diskusi tentang kesulitan belajar yang ditemui siswa. ${ }^{32}$

Wawancara dengan siswa kelas VIII di MTs Laboratorium Kota Jambi sebagai berikutsaya mendapatkan pujian dari guru saat kegiatan pembelajaran Al-Qur'an Hadits berlangsung. Hal ini dikarenakan saya lancar membaca ayat-ayat Al-Qur'an maupun Hadist, dan dengan cepat menghapalnya. Dengan demikian saya mendapat nilai tinggi dengan kemampuan saya dan menjadi termotivasi untuk lebih giat belajar. ${ }^{33}$ Hubungan yang akrab antara guru dan siswa demikian telah tercipta dengan memperhatikan minat belajar siswa. Hal ini mengingat hubungan yang tidak baik antara guru dengan siswa akan menyebabkan siswa mengalami kesulitan dalam belajar dan siswa menjadi tidak termotivasi untuk belajar.

\section{d. Memberikan Hukuman Secara Tepat}

Ketidaktepatan sanksi yang diberikan guru Al-Qur'an Hadits dalam hal ini terhadap pelanggaran disiplin belajar seperti yang datang terlambat di kelas atau yang ribut di kelas, membuat siswa menjadi leluasa untuk melemahkan disiplin pada diri mereka sendiri. Guru di MTs Laboratorium Kota Jambi merasa berkewajiban untuk meningkatkannya lagi menjadi lebih baik, agar kegiatan pembelajaran Al-Qur'an Hadits bisa berjalan normal. Observasi terhadap SM, guru yang mengajar Al-Qur'an Hadits di kelas VIII sebagai berikut agar siswa lebih aktif dalam belajar dan pembelajaran lebih efektif, maka guru menerapkan sanksi yang tepat dan mendidik bagi siswa misalnya menghafal kosakata arab atau ayat/hadis yang pendek, setelah sebelumnya guru juga telah memberikan nasehat dan teguran. Sanksi seperti tidak boleh mengikuti kegiatan belajar jika ribut di kelas, maka diperintahkan untuk berdiri di depan kelas sepanjang jam pelajaran

\footnotetext{
${ }^{32}$ Observasi, di MTs Laboratorium Kota Jambi

${ }^{33}$ Wawancara, di MTs Laboratorium Kota Jambi
} 
berlangsung, jika siswa malas mengikuti kegiatan pembelajaran, maka materi pelajaran akan ditambah dengan pekerjaan rumah dan lain sebagainya. Tindakan ini dipilih guru lakukan, karena menyesuaikan dengan kesalahan siswa yang tidak tiap hari melakukannya. ${ }^{34}$

Wawancara dengan seorang siswa yang mengikuti kegiatan pembelajaran Al-Qur'an Hadits kelas VIII di MTs Laboratorium Kota Jambi mengatakan bahwa sanksi lain yang diberikan guru kepada kami jika tidak mematuhi disiplin kelas adalah memberikan tugas lebih banyak lagi jika kami tidak mengerjakan tugas tepat pada waktunya. Meskipun ini sangat membebankan kami, namun kami menjadi tahu bahwa disiplin sangat berarti bagi siswa dalam belajar. Saya sendiri selama di kelas VIII ini hanya sekali terkena sanksi dari guru. ${ }^{35}$ Peningkatan disiplin siswa memang memerlukan ketegasan guru, dan guru di MTs Laboratorium Kota Jambi telah memiliki konsep yang jelas dalam meletakkan pondasi disiplin dalam setiap mengajar.

\section{e. Memberikan Tantangan dalam Belajar}

Tugas guru dalam menumbuhkan kesadaran siswa adalah memberikan sejumlah tantangan bagi siswa untuk dihadapi dengan sejumlah materi pelajaran yang diberikan. Pengamatan di kelas VIII terhadap SM, guru yang mengajar Al-Qur'an Hadits dimana guru memberikan hapalan ayat atau surat pendek dalam 2 minggu sekali, dan siswa yang bisa/cepat menghapal tepat waktu maka diberikan nilai. ${ }^{36}$ Arahan yang diberikan guru Al-Qur'an Hadits dalam membangkitkan peluang siswa untuk lebih baik lagi dalam belajar. Arahan yang berisikan upaya meningkatkan motivasi siswa dalam belajar telah dilakukan guru dalam mengajar PAIKEM.

\footnotetext{
${ }^{34}$ Observasi, di MTs Laboratorium Kota Jambi

${ }^{35}$ Wawancara, di MTs Laboratorium Kota Jambi

${ }^{36}$ Observasi, di MTs Laboratorium Kota Jambi
} 
c. Faktor Pendukung dan Penghambat Pembelajaran PAIKEM dalam Meningkatkan Minat Belajar Siswa pada Mata Pelajaran Al-Qur'an Hadits di MTs Laboratorium Kota Jambi

Faktor pendukung dan penghambat pembelajaran PAIKEM dalam meningkatkan minat belajar siswa pada mata pelajaran AlQur'an Hadits di MTs Laboratorium Kota Jambi adalah

a. Faktor Pendukung

1) Kepala Sekolah

Pembelajaran PAIKEM pada mata pelajaran Al-Qur'an Hadits yang dirancang guru MTs Laboratorium Kota Jambi perlu dimaksimalkan wujudkan dengan berkonsultasi kepada kepala sekolah. Sebelum mengajar, terlihat guru membuat sejumlah acuan atau persiapan mengajar. Pengamatan terhadap guru yang mengajar PAIKEM di MTs Laboratorium Kota Jambi telah menyusun silabus dalam mengajar pada mata pelajaran tersebut. ${ }^{37}$

Berdasarkan pengamatan terhadap guru di MTs Laboratorium Kota Jambi di atas dapat dipahami bahwa guru membuat sejumlah perencanaan dalam mengajar. Wawancara dengan MM, Kepala sekolah yang mengatakan bahwa penyusunan perencanaan pembelajaran AlQur'an Hadits dilakukan dengan membentuk kerja kelompok rekan sejawat. Dengan adanya kelompok ini guru dapat berdiskusi dan bertukar informasi mengenai kondisi pembelajaran dan kondisi belajar siswa di kelas. Dengan demikian, guru memiliki wadah untuk mengenal teknik penyusunan perencanaan pembelajaran Al-Qur'an Hadits lebih jauh dan lebih mendalam. ${ }^{38}$

Peningkatan penyusunan perencanaanPAIKEMdalam pembelajaran Al-Qur'an Hadits dalam upaya peningkatan mutu guru dilaksanakan kepala sekolah dengan cara sosialisasi penyusunan perencanaan pembelajaran Al-Qur'an Hadits di MTs Laboratorium Kota Jambi yang dilakukan kepala sekolah dengan membentuk kerja kelompok rekan sejawat bagi guru Al-Qur'an Hadits. Dengan demikian, guru memiliki wadah untuk mengenal penyusunan

${ }^{37}$ Observasi, di MTs Laboratorium Kota Jambi

${ }^{38}$ Wawancara, di MTs Laboratorium Kota Jambi 
perencanaan pembelajaran Al-Qur'an Hadits dengan rekannya yang lebih memahami itu.

Kerja sama yang intensif dilakukan kepala sekolah dengan guru diharapkan mampu memberikan gagasan baru bagi pelaksanaan evaluasi hasil belajar, karena adanya pola saling mendukung antara dua pihak yang berkepentingan dalam pembelajaran. Wawancara dengan MM, kepala MTs Laboratorium Kota Jambi yang mengatakan berbagai permasalahan yang timbul dalam mengajar selalu diselesaikan melalui rapat berkala dengan majelis guru yang diselenggarakan setiap 1 bulan sekali, diskusi dengan guru setiap guru dan lain sebagainya. Melalui upaya ini, guru bisa menuangkan gagasan yang bisa meningkatkan penyusunan perencanaan pembelajaran $\mathrm{Al}$ Qur'an Hadits. ${ }^{39}$

Selanjutnya SM, guru Al-Qur'an Hadits memberikan keterangan lebih lanjut tentang permasalahan tersebut, dimana mengatakan guru mengajar di MTs Laboratorium Kota Jambi cukup lama, namun pengalaman mengajar yang saya miliki belum sepenuhnya baik, sehingga dalam penyusunan perencanaan pembelajaran Al-Qur'an Hadits berbasis PAIKEM itu sendiri sering mendapat kendala dan hasil yang kurang memuaskan atau baik sebagaimana mestinya. Untuk itu saya berusaha melakukan dialog dengan kepala sekolah bagaimana melakukan pelaksanaan evaluasi hasil belajar yang lebih baik lagi. ${ }^{40}$

Berbagai permasalahan sering ditemui guru dalam penyusunan perencanaan pembelajaran Al-Qur'an Hadits. Untuk memecahkan masalah itu maka guru dan kepala sekolah melakukan kerja sama dalam penyusunan perencanaan pembelajaran Al-Qur'an Hadits secara maksimal. Saat diobservasi mengenai kerja sama menyangkut hal ini maka terlihat guru sering melakukan diskusi tentang permasalahan proses pembelajaran di MTs Laboratorium Kota Jambi. Hal ini meliputi, diskusi tentang penyusunan perencanaan pembelajaran Al-Qur'an Hadits, memberikan materi pelajaran yang

${ }^{39}$ Wawancara, di MTs Laboratorium Kota Jambi

${ }^{40}$ Wawancara, di MTs Laboratorium Kota Jambi 
kondusif terhadap siswa, tentang bentuk evaluasi yang baik, penegakan disiplin waktu dalam belajar dan lain sebagainya. ${ }^{41}$

Sedangkan wawancara dengan SM, guru Al-Qur'an Hadits juga mengatakan sebagai upaya peningkatan dalam penyusunan perencanaanpembelajaran, maka guru berusaha meminta saran dari kepala sekolah mengenai kinerja saya selama ini mengajar di MTs Laboratorium Kota Jambi. Kepala sekolah banyak memberikan masukan kepada guru tentang penyusunan perencanaan pembelajaran sesuai dengan tujuan pencapaian prestasi belajar siswa. ${ }^{42}$

Keadaan ini menjadi pendukung percepatan upaya peningkatan kompetensi guru di MTs Laboratorium Kota Jambi. Kegiatan kerja sama dengan kepala sekolah guna mencari solusi pemecahan masalah untuk kemajuan penyusunan perencanaan pembelajaran Al-Qur'an Hadits di MTs Laboratorium Kota Jambi. Dari hasil pengamatan penulis terhadap kepala sekolah di mana selaku kepala sekolah tetap memberikan dukungan sepenuhnya kepada seluruh guru termasuk guru untuk mengikuti wadah pelatihan yang bisa mendukung guru dalam meningkatkan minat belajar siswa, seminar maupun lokakarya dalam meningkatkan mutu pembelajaran berbasis PAIKEM. ${ }^{43}$

Lebih lanjut penulis kemukakan dari hasil wawancara dengan SM, guru Al-Qur'an Hadits mengatakan guru berusaha menyadari bahwa dalam penyusunan perencanaan pembelajaran Al-Qur'an Hadits sangat dibutuhkan kerja keras sehingga saya harus lebih meningkatkan kualitas dalam pembelajaran, termasuk profesionalitas guru Al-Qur'an Hadits. Dorongan dan semangat dari seluruh lingkungan sekolah, serta minat belajar siswa untuk aktif dalam pembelajaran memotivasi untuk lebih profesional. ${ }^{44}$

Berdasarkan hasil wawancara, upaya peningkatan mutu guru dalam penyusunan perencanaan pembelajaran Al-Qur'an Hadits dilakukan dengan menyediakan waktu sebanyak mungkin bagi guru untuk bisa berkonsultasi dengan kepala sekolah, dukungan eksternal

\footnotetext{
${ }^{41}$ Observasi, di MTs Laboratorium Kota Jambi

${ }^{42}$ Wawancara, di MTs Laboratorium Kota Jambi

${ }^{43}$ Observasi, di MTs Laboratorium Kota Jambi

${ }^{44}$ Wawancara, di MTs Laboratorium Kota Jambi
} 
yang datang dari pihak lain yang menyelenggarakan pelatihan dan penataran. Faktor yang mendukung dalam meningkatkan minat belajar siswa di MTs Laboratorium Kota Jambi ini sangat membantu pelaksanaan pembelajaran selama ini.

\section{2) Pelatihan Guru}

Upaya yang dilakukan untuk mengatasi kurangnya pengalaman mengajar secara PAIKEM, maka pelatihan menjadi pilihan meningkatkan kemampuan guru. Pihak sekolah melakukan koordinasi dengan Kementerian Agama Kabupaten Sarolangun. Melalui koordinasi ini, pihak sekolah dapat mengikuti organisasi guru yaitu Musyawarah Guru Mata Pelajaran (MGMP) dan Kelompok Kerja Guru (KKG). ${ }^{45}$ Kegiatan ini dilakukan di bawah koordinasi Dinas Pengawas Sekolah, dan untuk setiap mata pelajaran dipimpin langsung oleh guru senior yang ditunjuk oleh kepala sekolah. Guru juga dapat mengikuti pelatihan kurikulum, seminar maupun lokakarya.

Hal ini ditegaskan oleh SM yang mengatakan bahwa melalui organisasi guru MGMP dan KKG, guru untuk setiap mata pelajaran bisa melakukan kegiatan rutin bertemu satu kali setiap minggu guna menyusun model pembelajaran dan mengatasi masalah yang muncul. Di samping itu, MGMP dan KKG bisa mengundang para ahli pendidikan di luar, baik ahli subtansi mata pelajaran untuk membantu guru dalam memahami materi yang masih dianggap sulit atau membantu memecahkan masalah yang muncul di kelas, maupun berbagai metode pembelajaran untuk menemukan cara yang paling sesuai dalam membentuk kompetensi tertentu. Guru juga dapat mengikuti pelatihan, seminar maupun lokarya untuk meningkatkan pemahaman terhadap perencanaanpembelajaran Al-Qur'an Hadits. Guru Al-Qur'an Hadits pernah mengikuti pendidikan dan pelatihan. Hal ini sangat bermanfaat untuk menambah wawasan keilmuan penulis dalam mengajar berbasis PAIKEM. ${ }^{46}$

\footnotetext{
${ }^{45}$ Observasi, di MTs Laboratorium Kota Jambi

${ }^{46}$ Wawancara, di MTs Laboratorium Kota Jambi
} 
Berdasarkan hal di atas dapat dipahami bahwa upaya yang dilakukan dalam mengatasi kurangnya koordinasi dengan instansi terkait yaitu pihak sekolah melakukan kerja sama dengan semua pihak dan segera melakukan koordinasi dengan Depertemen Agama Kabupaten Sarolangun. Melalui koordinasi ini pihak sekolah dapat mengikuti MGMP dan KKG maupun pelatihan KTSP, seminar dan lokakarya.

Kepala sekolah memiliki peran dan fungsi yang strategis dalam melaksanakan tugasnya sebagai pimpinan untuk memberikan pengayoman kepada setiap guru untuk bisa melaksanakan peningkatan kualitas guru secara layak dan maksimal.

SM mengatakan bahwa guru memperoleh manfaat dari pelatihan-penataran yang diadakan oleh sekolah tersebut, terutama dalam peningkatan inovasi-inovasi pembelajaran pada mata pelajaran saat ini serta mengikuti perkembangan media dan metode pembelajaran modern. Hal ini sejalan dengan pernyataan salah seorang guru yang mengikuti pelatihan mengatakan dengan adanya pelatihan guru mendapat informasi baru dan perkembangan dunia pendidikan luar, guru tahu bahwa dunia pendidikan berkembang sesuai dengan perkembangan zaman, jadi dengan adanya pelatihan guru akan mampu berinovasi dalam mengajar. ${ }^{47}$

Masih menurut SM, pengiriman guru untuk mengikuti sejumlah penataran dan pelatihan tersebut juga merupakan salah satu tindak lanjut dari penilaian kinerja. Hanya saja tidak semua guru memperoleh kesempatan untuk dikirim keluar, tergantung permintaan dari pihak yang mengundang. ${ }^{48}$ Guru Al-Qur'an Hadits juga menyusun silabus dalam mengajar pada mata pelajaran tersebut. Sebelum mengajar, terlihat guru membuat sejumlah acuan atau persiapan mengajar. Pengamatan terhadap guru Al-Qur'an Hadits yang mengajar di MTs Laboratorium Kota Jambi telah menyusun silabus dalam mengajar pada mata pelajaran tersebut. Guru mengajar

\footnotetext{
${ }^{47}$ Wawancara, di MTs Laboratorium Kota Jambi

${ }^{48}$ Wawancara, di MTs Laboratorium Kota Jambi
} 
di kelas dengan persiapan sebelum masuk kelas untuk memberikan materi pelajaran berbasis PAIKEM. ${ }^{49}$

Temuan di lapangan menunjukkan bahwa pengiriman peserta untuk mengikuti pelatihan keluar baik nasional maupun lokal tidak didasarkan pada kebutuhan sekolah, tetapi lebih didasarkan pada program dinas/instansi pelaksanaan sehingga tema-tema pelatihan yang ditawarkan juga adalah tema-tema umum, jika ada tema pelatihan seperti penataran guru mata pelajaran jumlahnya pun sangat terbatas sehingga tidak menyentuh kebutuhan guru Al-Qur'an Hadits.

\section{3) Kesiapan Guru Mengajar}

Efektivitas PAIKEMuntuk meningkatkan minat belajar siswa pada mata pelajaran Al-Qur'an Hadits di MTs Laboratorium Kota Jambi ditentukan dengan perencanaan pembelajaran PAIKEM yang tepat. Perencanaan pada jangka waktu tertentu yang berisi tentang apa yang akan dilakukan guru dalam persiapan mengajar. Dengan demikian, persiapan mengajar merupakan upaya untuk memperkirakan tindakan yang akan dilakukan dalam kegiatan pembelajaran PAIKEM. Perencanaan pembelajaran PAIKEM perlu dilakukan untuk mengkoordinasikan komponen pembelajaran seperti standar kompetensi, kompetensi dasar, materi pelajaran, media dan sumber pembelajaran serta penilaian pembelajaran. Mengenai perencanaan pembelajaran, berikut wawancara dengan SM yang mengatakan bahwa untuk melakukan perencanaan pembelajaran AlQur'an Hadits di kelas, maka terlebih dahulu guru menyiapkan beberapa hal tentang pembelajaran itu sendiri. Hal itu meliputi mempersiapkan standar kompetensi, kompetensi dasar, materi pelajaran, kegiatan pembelajaran, alat dan sumber pembelajaran serta penilaian pembelajaran dalam suatu materi yang akan saya ajarkan nantinya di kelas. ${ }^{50}$

Dalam menyukseskan pembelajaran PAIKEM bagi peningkatan minat belajar siswa, guru tetap memulainya dari mengelola program

${ }^{49}$ Observasi, di MTs Laboratorium Kota Jambi

${ }^{50}$ Wawancara, di MTs Laboratorium Kota Jambi 
dimulai dari perencanaan Program Tahunan, Program Semester, Silabus dan RPP, untuk mengidentifikasi standar kompetensi, kompetensi dasar, materi pelajaran, kegiatan pembelajaran, alat dan sumber pembelajaran serta penilaian pembelajaran. Observasi penulis sebagai berikut bahwa guru Al-Qur'an Hadits mempersiapkan RPP yang memperhatikan standar kompetensi, kompetensi dasar, materi pelajaran, kegiatan pembelajaran, alat dan sumber pembelajaran serta penilaian pembelajaran. ${ }^{51}$

Pengamatan terhadap guru Al-Qur'an Hadits di MTs Laboratorium Kota Jambi sebagai berikut bahwa guru Al-Qur'an Hadits melakukan persiapan pembelajaran secara sendiri. Tidak ada kegiatan untuk melibatkan pihak lain dalam kegiatan tersebut. ${ }^{52}$ Hasil wawancara penulis dengan MM, kepala sekolah yang mengatakan setiap pembelajaran mata pelajaran apapun, setiap guru diwajibkan membuat perencanaan pembelajaran yang meliputi program jangka penjang maupun program jangka pendek. Hal ini dikarenakan salah satu faktornya adalah adanya keinginan bersama untuk membangun sekolah ini menjadi sekolah terbaik, dan salah satu usahanya adalah membuat lulusan dari sekolah ini menjadi yang terbaik pula di tingkat sekolah yang sama. Hal itu bisa terwujud salah satunya adalah jika guru tersebut membuat perencanaan yang sistematis dan kontinu dalam proses pembelajaran itu sendiri. ${ }^{53}$

Senada dengan hal tersebut maka peneliti mewawancarai SM, guru Al-Qur'an Hadits dan kutipan wawancaranya adalah sebagai berikut pada pembelajaran PAIKEMpada mata pelajaran Al-Qur'an Hadits, maka guru membuat program pembelajaran baik secara program jangka panjang maupun program jangka pendek. ${ }^{54}$

Setelah diobservasi terlihat bahwa pembuatan perencanaan program pembelajaran PAIKEM yang merupakan landasan utama bagi seorang guru dalam pembelajaran jangka waktu yang agak panjang nampaknya direalisasikan sebagaimana mestinya. Program

\footnotetext{
${ }^{51}$ Observasi, di MTs Laboratorium Kota Jambi

${ }^{52}$ Observasi, di MTs Laboratorium Kota Jambi

${ }^{53}$ Wawancara, di MTs Laboratorium Kota Jambi

${ }^{54}$ Wawancara, di MTs Laboratorium Kota Jambi
} 
perencanaan pembelajaran dalam meningkatkan minat belajar siswa tersebut meliputi program tahunan, semester, satuan pembelajaran dan rencana pembelajaran. Pada dasarnya yang menjadi isi dari program semester pada mata pelajaran Al-Qur'an Hadits adalah apa yang tercantum dalam silabus, tetapi beberapa pengaturan kembali dilakukan untuk perluasan dan kelengkapan sehingga membentuk suatu program pembelajaran. ${ }^{55}$

Wawancara dengan SM di MTs Laboratorium Kota Jambi yang mengatakan bahwa media pembelajaran sangat penting sekali keberadaannya dalam mengefektifkan persiapan mengajar guru. Ada bagian dari materi pelajaran yang sangat membutuhkan media seperti pada pokok bahasan sejarah awal Islam yang membutuhkan media buku cerita, namun demikian guru jarang mencantumkan metode cerita dalam kegiatan perencanaan pembelajaran. ${ }^{56}$

Berdasarkan wawancara dengan guru Al-Qur'an Hadits dan siswa di MTs Laboratorium Kota Jambi dapat diketahui bahwa kondisi media pembelajaran pada mata pelajaran Al-Qur'an Hadits memiliki jumlah media yang sangat terbatas untuk membantu merumuskan tujuan pembelajaran secara tepat. Seharusnya media sebagai salah satu sumber belajar ikut membantu guru memperkaya wawasan anak didik. Aneka macam bentuk dan jenis media pendidikan yang digunakan oleh guru menjadi sumber ilmu pengetahuan bagi anak didik.

MTs Laboratorium Kota Jambi dalam proses pembelajaran PAIKEM telah menggunakan Kurikulum 2013, penerapannya telah dilaksanakan dengan baik sesuai dengan peraturan yang ada. Namun di dalam proses pembelajaran pada mata pelajaran Al-Qur'an Hadits, guru di MTs Laboratorium Kota Jambi kesulitan menggunakan media pembelajaran. Kesadaran guru mengenai pentingnya keberadaan media dalam mengajar di kelas tentunya sangat diperlukan. Guru yang mengajar sangat tergantung kepada media. Mengenai penting atau tidaknya media pembelajaran di MTs Laboratorium Kota Jambi maka peneliti mewawancarai SM di MTs Laboratorium Kota Jambi yang

${ }^{55}$ Observasi, di MTs Laboratorium Kota Jambi

${ }^{56}$ Wawancara, di MTs Laboratorium Kota Jambi 
mengatakan bahwa bagi guru urgensi media dalam proses pembelajaran sangat penting. Komunikasi yang sangat dilakukan di kelas terkadang mudah jika media pembelajaran memadai, meskipun media yang ada masih terbatas. ${ }^{57}$

Media mempertinggi kegiatan belajar anak didik dalam tenggang waktu yang cukup lama. Ini berarti kegiatan belajar anak didik dengan bantuan media akan menghasilkan hasil belajar yang lebih baik daripada tanpa bantuan media. Setiap materi pelajaran tentu memiliki tingkat kesukaran yang bervariasi. Pada satu sisi ada bahan pelajaran yang tidak memerlukan alat bantu, tetapi dipihak lain ada bahan pelajaran yang sangat memerlukan alat bantu berupa media pembelajaran seperti mikroskop, jenis-jenis hewan yang diawetkan dan sebagainya.

Wawancara dengan SM di MTs Laboratorium Kota Jambi yang mengatakan bahwa peranan media pembelajaran adalah sebagai alat bantu untuk mempermudah memahami pelajaran yang diberikan dan bisa mengembangkan materi pelajaran. Walau demikian selama MTs Laboratorium Kota Jambi mendapatkan bantuan media pada mata pelajaran Al-Qur'an Hadits, guru belum pernah menggunakannya untuk praktek. ${ }^{58}$

Guru Al-Qur'an Hadits telah menyadari bahwa metode yang dipakai mempengaruhi pembelajaran PAIKEM yang berlangsung, sehingga dengan demikian guru mengevaluasi metode yang digunakan dalam pembelajaran, apakah sesuai dengan anak didik atau tidak. Jadi di samping interaksi, guru juga telah memilih metode yang tepat sehingga membangkitkan semangat siswa untuk mengikuti pelajaran. Media sebagai alat bantu dalam proses pembelajaran di MTs Laboratorium Kota Jambi masih sangat terbatas, padahal hal ini sangat dibutuhkan untuk membantu tugas guru dalam menyampaikan pesanpesan dari bahan pelajaran. Guru sadar bahwa tanpa bantuan media, maka bahan pelajaran sukar dicerna dan dipahami oleh setiap anak didik, terutama bahan pelajaran yang rumit.

\footnotetext{
${ }^{57}$ Wawancara, di MTs Laboratorium Kota Jambi

${ }^{58}$ Wawancara di MTs Laboratorium Kota Jambi
} 


\section{4) Sistem Disiplin Sekolah}

Disiplin guru apabila dikembangkan dan diterapkan dengan baik, konsisten dan konsekuen akan berdampak positif bagi kehidupan dan kualitas guru. Disiplin dapat mendorong mereka mengajar dengan kongkrit dan praktik hidup di sekolah tentang hal-hal positif: melakukan hal-hal yang lurus dan benar, menjauhi hal-hal yang negatif. Dengan memberlakukan disiplin, guru dapat mengajar dengan lingkungan yang baik, sehingga muncul keseimbangan diri dalam hubungan dengan orang lain. Jadi, disiplin menata perilaku seseorang dalam hubungannya di tengah-tengah lingkungannya. Upaya kepala MTs Laboratorium Kota Jambi dalam melakukan pengawasan disiplin guru adalah sebagai berikut kepala sekolah melakukan pengawasan terhadap guru dalam merancang rencana pembelajaran Al-Qur'an Hadits. Tujuan dilakukan hal ini adalah melihat disiplin guru dalam membuat perangkat pembelajaran Al-Qur'an Hadits berbasis PAIKEM. ${ }^{59}$

Observasi penulis menemukan bahwa upaya guru meningkatkan mutunya dengan meningkatkan disiplin dalam membuat perangkat mengajar. Untuk menegakkan disiplin tidak selamanya harus melibatkan orang lain, tetapi melibatkan diri sendiri juga bisa. Artinya menegakkan disiplin dari diri sendiri. Upaya inilah yang telah dibudayakan di MTs Laboratorium Kota Jambi. Kepala sekolah bersama dengan majelis guru menyusun perangkat mengajar di awal tahun baru, untuk meningkatkan disiplin guru dalam merancang pembelajaran Al-Qur'an Hadits di MTs Laboratorium Kota Jambi ini. ${ }^{60}$

Dalam mengajar disiplin sangat diperlukan. Disiplin dapat melahirkan semangat menghargai waktu, bukan menyia-nyiakan waktu berlalu dalam kehampaan. Wawancara dengan SM di MTs Laboratorium Kota Jambi juga mengatakan kepala sekolah selalu memperhatikan kondisi disiplin guru. Hal ini dimaksudkan untuk melihat perilaku guru dalam mematuhi peraturan sekolah yang ada.

${ }^{59}$ Observasi, di MTs Laboratorium Kota Jambi

${ }^{60}$ Observasi, di MTs Laboratorium Kota Jambi 
Dengan adanya pengawasan ini, guru menjadi termotivasi untuk lebih profesional dalam membuat perangkat mengajar tepat waktu. ${ }^{61}$

Wawancara dengan MM, kepala sekolah mengatakan bahwa disiplin juga menjadi media untuk meningkatkan kualitas guru secara berkesinambungan. Dalam mendidik disiplin berperan mempengaruhi, mendorong, mengendalikan, mengubah, membina dan membentuk perilaku-perilaku tertentu sesuai dengan nilai-nilai yang ditanamkan, diajarkan dan diteladankan. Karena itu, perubahan perilaku seseorang, termasuk kualitas guru dalam perencanaan rencana pembelajaran AlQur'an Hadits berbasis PAIKEM. ${ }^{62}$

Observasi penulis dimana kepala sekolah yang berusaha meningkatkan kinerja guru secara efektif. Kelemahan di bidang ini terletak pada kurangnya pemberian motivasi, bimbingan dan penerapan disiplin, baik yang dilakukan oleh kepala sekolah dan para wakilnya, serta kepada guru Al-Qur'an Hadits itu sendiri. ${ }^{63}$

Disiplin guru apabila dikembangkan dan diterapkan dengan baik, konsisten dan konsekuen akan berdampak positif bagi kehidupan dan kualitas guru. Disiplin dapat mendorong mereka mengajar dengan kongkrit dan praktik hidup di sekolah tentang hal-hal positif: melakukan hal-hal yang lurus dan benar, menjauhi hal-hal yang negatif. Dengan memberlakukan disiplin, guru dapat mengajar dengan lingkungan yang baik, sehingga muncul keseimbangan diri dalam hubungan dengan orang lain. Jadi, disiplin menata perilaku seseorang dalam hubungannya di tengah-tengah lingkungannya. Upaya kepala MTs Laboratorium Kota Jambi dalam melakukan pengawasan disiplin guru adalah sebagai berikut kepala sekolah melakukan pengawasan terhadap guru dalam penyusunan perencanaan pembelajaran AlQur'an Hadits. Tujuan dilakukan hal ini adalah melihat disiplin guru dalam membuat perangkat mengajar dan menerapkan kurikulum sesuai persiapan yang ada. ${ }^{64}$

\footnotetext{
${ }^{61}$ Wawancara, di MTs Laboratorium Kota Jambi

${ }^{62}$ Wawancara, di MTs Laboratorium Kota Jambi

${ }^{63}$ Observasi, di MTs Laboratorium Kota Jambi

${ }^{64}$ Observasi, di MTs Laboratorium Kota Jambi
} 
Wawancara dengan MM mengatakan bahwa upaya guru meningkatkan mutunya dengan meningkatkan disiplin dalam membuat perangkat mengajar. Untuk menegakkan disiplin tidak selamanya harus melibatkan orang lain, tetapi melibatkan diri sendiri juga bisa. Artinya menegakkan disiplin dari diri sendiri. Upaya inilah yang telah dibudayakan di MTs Laboratorium Kota Jambi. Kepala sekolah bersama dengan majelis guru menyusun perangkat mengajar di awal tahun baru, untuk meningkatkan disiplin guru dalam meningkatkan minat belajar siswa di MTs Laboratorium Kota Jambi ini. ${ }^{65}$

Salah satu budaya sekolah yang harus dikembangkan adalah kedisiplinan. Kedisiplinan bagi guru sedikit banyak akan mempengaruhi hasil mengajarnya dan kedisiplinan ini harus dimulai dari guru sebagai teladan yang utama. Dilihat dari fakta di atas menunjukkan kurangnya disiplin guru dalam membuat perangkat mengajar berbasis PAIKEM. Untuk menumbuhkan disiplin guru ini, seyogyanya kepala sekolah senantiasa memberikan motivasi bimbingan serta menegakkan disiplin dan memberikan teguran kepada para guru untuk giat mengikuti aktivitas mengajar yang dipandang bermanfaat dan mampu membantu terwujudkanya tujuan sekolah.

b. Faktor Penghambat

Faktor penghambat dalam meningkatkan minat belajar siswa di MTs Laboratorium Kota Jambi adalah:

\section{1) SDM Guru}

Guru yang baik bisa meningkatkan kemampuannya secara profesional. Guru harus memahami dengan baik bidang keguruan yang ditekuninya. Guru senantiasa menegakkan prinsip profesionalitasnya, termasuk dalam pengelolaan kelas. Dengan pengelolaan kelas, maka suasana pembelajaran diharapkan menjadi kondusif karena terkontrol melalui pengawasan guru terhadap kelas secara fisik maupun non fisik (siswa). Observasi penulis terhadapSM, guru Al-Qur'an Hadits di mana kekurangan informasi mengenai model PAIKEM ini masih terlihat pada diri guru seperti tidak adanya guru memiliki buku PAIKEM,

${ }^{65}$ Wawancara, di MTs Laboratorium Kota Jambi 
jarangnya guru mencari informasi secara online mengenai PAIKEM dan penguasaan guru terhadap PAIKEM masih nonoton. ${ }^{66}$

Pengamatan penulis di kelas VIII melaksanakan pengelolaan siswa yang dilaksanakan sebelum pelajaran dimulai yaitu dimana setelah lonceng berbunyi tanda pelajaran dimulai, guru mempersilahkan mereka masuk kelas secara tertib. Lalu pelajaran pertama didahului dengan doa. Kemudian guru mengadakan pencatatan terhadap siswa yang hadir dan tidak hadir. Siswa MTs Laboratorium Kota Jambi yang berhalangan mengikuti pelajaran (karena sakit, dan sebagainya) terlihat menyampaikan surat keterangan berhalangan kepada guru. Namun di luar kelas, masih ada siswa yang terlambat datang ke sekolah karena jauh lokasi rumah dari sekolah dan ada yang masih membantu orang tua bekerja di rumah sebelum bersekolah. ${ }^{67}$

Berdasarkan observasi di atas maka pelaksanaan pengelolaan siswa sebelum pelajaran dimulai dilakukan dengan dimana mengatur siswa untuk tertib masuk kelas dan berdoa sebelum memulai pelajaran serta guru mengisi absensi siswa sebelum mengajar, meskipun dalam pelaksanaanya guru masih dihadapkan pada siswa yang terlambat datang ke sekolah.

Guru harus memperhatikan akan kemajuan siswa-siswi, dan harus mampu menelaah materi pelajaran, sehingga guru tidak hanya terpaku pada satu buku saja. Dalam kegiatan pembelajaran tidak semua siswa mampu berkonsentrasi dalam waktu yang relatif lama pada satu metode. Daya serap siswa terhadap bahan yang diberikan juga bermacam-macam; ada yang cepat, ada yang sedang, dan ada yang lambat. Cepat lambatnya penerimaan siswa terhadap bahan pelajaran yang diberikan menghendaki pemberian metode yang bervariasi, sehingga penguasaan penuh dapat tercapai.

Wawancara penulis dengan siswa mengatakan: "Kami melihat guru mengajar di kelas menggunakan metode ceramah tentang mata pelajaran Al-Qur'an Hadits pada materi Hikmah Puasa Ramadhan,

${ }^{66}$ Observasi, di MTs Laboratorium Kota Jambi

${ }^{67}$ Observasi, di MTs Laboratorium Kota Jambi 
kami hanya mendengarkan penjelasan guru, meskipun hal ini sangat membosankan." 68

Pengamatan penulis terhadap guru Al-Qur'an Hadits yang mengajar di kelas VIII dimana kegiatan pembelajaran yang berlangsung diawali dengan menjalin keakraban, kemudian dilanjutkan dengan memberikan materi pokok bahasan tersebut dengan menggunakan metode ceramah. Aktivitas siswa dalam hal ini adalah mendengarkan penjelasan guru, ceramah dan pengarahan, meskipun ada juga siswa yang kurang perhatian terhadap aktivitas belajar yang mereka lakukan. ${ }^{69}$ Berdasarkan keterangan di atas berarti sehubungan dengan kompetensi guru sebagai tenaga profesional, maka guru bertanggung jawab untuk menciptakan kondisi pembelajaran yang kondusif berbasis PAIKEM.

\section{2) Efektivitas Waktu Pelaksanaan PAIKEM}

Efektivitas waktu pelaksanaan PAIKEM sangat tergantung dengan kesediaan dan penguasaan siswa terhadap materi Al-Qur'an Hadits yang diajarkan guru. Artinya pendidikan siswa sangat memudahkan guru menerapkan model PAIKEM. Maksud dari latar belakang pendidikan siswa di sini adalah jenis pendidikan formal ataupun informal yang pernah diikuti oleh siswa, seperti pengajian di rumah atau pendidikan sebelum siswa masuk ke MTs Laboratorium Kota Jambi ini. Siswa yang pernah atau ikut dalam pengajian tertentu seperti di rumah atau di tempat-tempat pengajian, akan berbeda dengan siswa yang hanya mengandalkan pengetahuan yang mereka peroleh dari sekolahan sebelum mereka masuk MAN ini.

Siswa yang sering ikut pengajian atau sering mendengar tentang materi tersebut akan lebih mudah untuk menerima dan paham apa yang akan diajarkan oleh guru tersebut daripada siswa yang belum pernah sama sekali mendengar materi itu atau belum pernah mendengarnya. Menurut keterangan SM, guru Al-Qur'an Hadits mengemukakan sebagai berikut semakin nampak perbedaan antara siswa yang biasa ikut pengajian di rumah atau melalui jalur-jalur

${ }^{68}$ Wawancara, di MTs Laboratorium Kota Jambi

${ }^{69}$ Observasi, di MTs Laboratorium Kota Jambi 
pendidikan agama di lingkungan sekitarnya dengan siswa yang tidak pernah. Di saat pemberian tugas dimana seringkali siswa yang tidak begitu paham akan pelajaran agama ini tidak bisa menyelasaikan secara optimal akan tugas yang diberikan.”70

Berdasarkan wawancara di atas dapat diketahui bahwa semakin nampak perbedaan antara siswa yang biasa ikut pengajian di rumah atau melalui jalur-jalur pendidikan agama di lingkungan sekitarnya dengan siswa yang tidak pernah. Hal ini terlihat dari pemberian tugas dimana seringkali siswa yang tidak begitu paham akan pelajaran agama ini tidak bisa menyelasaikan secara optimal.

Latar belakang pendidikan ini sangat penting karena akan memberikan pengaruh yang berbeda bagi pemahaman siswa terhadap materi yang akan diajarkan guru Al-Qur'an Hadits di sekolah. Dari hasil observasi penulis, latar belakang pendidikan siswa baik yang formal maupun yang informal berbeda-beda, hal ini dapat dilihat dari cara menjawab pertanyaan yang diajukan guru kelas untuk beberapa soal-soal latihan pada materi pelajaran tertentu. ${ }^{71}$

Berdasarkan pernyataan di atas jelaslah bahwa latar belakang pendidikan siswa ini bisa menjadi hambatan bagi guru mendesain media yang sesuai dengan kebutuhan siswa. Menganalisis kebutuhan dan karakteristik siswa dalam menggunakan media pembelajaran dalam kurikulum Al-Qur'an Hadits juga membutuhkan prinsip kebutuhan anak. Sebagaimana yang diketahui bahwa hasil itu bukan dibawa dari lahir, namun setelah beberapa waktu, kemudian terutama dalam hal proses belajar hal ini banyak dirasakan faktor-faktor yang mempengaruhinya. Dari faktor ini sangat penting gunanya dalam menentukan desain media pembelajaran.

\section{3) Ketersediaan Sarana dan Prasarana (Media)}

Upaya guru meningkatkan mutunya diawali dari pemanfaatan perpustakaan secara maksimal. Perpustakaan adalah suatu istilah yang tidak asing lagi bagi setiap orang, terutama bagi pelajar. Hampir semua orang tahu apa itu perpustakaan, kecuali mereka yang tidak

\footnotetext{
${ }^{70}$ Wawancara, di MTs Laboratorium Kota Jambi

${ }^{71}$ Observasi, di MTs Laboratorium Kota Jambi
} 
pernah duduk di bangku madrasah. Di MTs Laboratorium Kota Jambi ditemukan banyak siswa yang memanfaatkan pustaka sebagai sumber belajar. Ada sebagian yang menggunakannya untuk mencari buku sebagai sumber tugas dan ada juga yang hanya membaca sebagai cakrawala pengetahuan. Terlihat juga mereka selalu melakukannya setiap ada kesempatan untuk istirahat. Meskipun banyak juga siswa yang malas melakukannya, dan buku yang ada di perpustakaan itu pun sangat terbatas.

Observasi penulis terhadap guru, SM, dimana pilihan media bagi guru masih sangat terbatas. pihak madrasah melakukan pengadaan buku-buku teks pembelajaran yang sesuai silabus dan pengadaan buku LKS bagi siswa. Dari segi media pembelajaran mengupayakan agar tersedianya media sehingga bisa digunakan dalam pembelajaran. ${ }^{72}$ Berdasarkan wawancara tersebut, dapat diketahui bahwa pihak madrasah melakukan pengadaan buku-buku teks pembelajaran yang sesuai dengan silabus dan pengadaan buku LKS bagi siswa. Sedangkan dari segi media pembelajaran, mengupayakan agar tersedianya media pembelajaran.

Untuk menghindari kekurangan sumber belajar siswa, tentu sangat dibutuhkan keberadaan pustaka sebagai wadah untuk mempelajari berbagai ilmu pengetahuan bagi siswa. Untuk itu di MTs Laboratorium Kota Jambi saya menganjurkan kepada siswa untuk selalu menyempatkan diri membaca buku di pustaka di madrasah ini. Melalui anjuran guru, diharapkan siswa tetap bisa memanfaatkan perpustakaan sebagai sumber belajar pendukung di samping belajar di kelas dengan guru. Dengan upaya ini, kepala MTs Laboratorium Kota Jambi telah berupaya menghasilkan kondisi pembelajaran yang efektif.

\section{PENUTUP}

Hasil temuan di lapangan tentang model PAIKEM dalam meningkatkan minat belajar siswa padamata pelajaran Al-Qur'an

${ }^{72}$ Observasi, di MTs Laboratorium Kota Jambi 
Hadits di MTs Laboratorium Kota Jambi karena belum memperhatikan psikologi dan kebutuhan belajar siswa, dengan rincian sebagai berikut: 1. Efektivitas PAIKEMuntuk meningkatkan minat belajar siswa pada mata pelajaran Al-Qur'an Hadits di MTs Laboratorium Kota Jambibelum tercapai. Meskipun guru melaksanakan pembelajaran aktif, inovatif, kreatif, efektif dan menyenangkan memilih dan menggunakan alat dan media pembelajaran yang terbatas, namun tetapmemberikan stimuli kepada siswa seperti mendorong siswa giat belajar, memberikan reward dan punishment, memperhatikan perkembangan invididual setiap siswa dalam belajar di kelas. Guru juga melakukan evaluasi untuk memastikan belajar tetap kondusif.

2. Upaya guru Al-Qur'an Haditsuntuk meningkatkan minat belajar siswa di MTs Laboratorium Kota Jambi dengan memberi angka kepada siswa, siswa bisa mengetahui hasil belajarnya, memberi pujian kepada siswamemberikan hukuman secara tepat kepada siswa yang bersalah dan memberikan tantangan dalam belajar.

3. Faktor pendukung dan penghambat pembelajaran PAIKEM dalam meningkatkan minat belajar siswa pada mata pelajaran Al-Qur'an Hadits di MTs Laboratorium Kota Jambi adalah kedisiplinan guru dalam mengajar dan tersedianya pelatihan guru dalam meningkatkan wawasan mengajar dan mendidik yang lebih baik. Faktor penghambat bagi guru adalah motivasi belajar sebagian siswa masih rendah, sumber belajar yang terbatas, dan kesiapan belajar siswa belum maksimal dalam menerima pelajaran.

\section{Daftar Pustaka}

Abdul Rahman Shaleh, Psikologi Suatu Pengantar dalam Perspektif Islam Jakarta: Kencana Prenada Media Group, 2009.

Daryanto, Belajar dan Mengajar. Bandung: CV. Yrama Widya, 2010.

Lexy J. Meleong, Metodologi Penelitian Kualitatif. Bandung: Remaja Rosdakarya, 2013.

Marsih, Analisis Pengembangan PAIKEM dalam Peningkatan Mutu Pendidikan Dasar di Kecamatan Singosari Kabupaten Malang, 
Tesis, Program Pascasarjana Universitas Muhammadiyah Malang, 2011.

Masitoh dan Laksmi Dewi, Strategi Pembelajaran. Jakarta: Direktorat Jenderal Pendidikan Islam Departemen Agama RI, 2009

Ramayulis, Metodologi Pengajaran Agama Islam. Jakarta: Kalam Mulia, 2001.

Rudi Hartono, Ragam Model Mengajar yang Mudah Diterima Murid Yogyakarta: Diva Press, 2013.

Syahidin, Menelusuri Metode Pendidikan dalam Al-Qur'an, Bandung: Alfabeta, 2009.

Yoel Octobe Purba, Perbedaan Kemampuan Berpikir Kreatif dan Pemecahan Masalah Matematis Siswa yang diberi Pembelajaran Berbasis Masalah dengan Pembelajaran PAIKEM. Tesis.Medan: Program Studi Pendidikan Matematika Pascasarjana Universitas Negeri Medan, 2015. 